\title{
The Erasmus Student Mobility Program and Its Contribution to Multicultural Education : The Case of Tecnological Education Institute of Thessaly
}

\section{Patsikas Stilianos}

\author{
Professor, Department of Accounting, TEl of Piraeus, Greece \\ spatsikas@yahoo.gr \\ Aspridis Georgios
}

Assistant Professor, aspridis@teilar.gr

Kazantzi Vasilik

Assistant Professor, kazantzi@teilar.gr

Sdrolias Labros

Associate Professor, Department of Project Management, TEl of Thessaly, Greece Isdrolias@teilar.gr

\section{Doi:10.5901/jesr.2013.v4n3p181}

\section{Abstract}

\begin{abstract}
Erasmus is an EU action plan in education that enables both students and academics to be "moved" between European universities, in the twenty-eight EU member countries, including the countries of the European Economic Area and Turkey. It took its name after the philosopher, theologian and humanist of the 15th century, Erasmus, also known as the "spiritual father of the reform". The Erasmus program was first established in 1987, providing the possibility for 3,000 students to move within the EU domain in the same year. Currently $90 \%$ of the European Higher Education Institutions participate in the program. It has after all evolved into a social and cultural phenomenon that goes beyond its conventional establishment providing a multiperspective and holistic learning experience, and creating a space where young people can meet and share ideas, knowledge and experiences within a convenient and relaxed context. The Erasmus can be studied in two dimensions. The first dimension is dictated by the opportunities provided to students to come into contact not only with the culture of the country they stay during the Erasmus program, but also with many other different cultures. This is attributed to the fact that students from around the world live together for several months, but also organize trips to neighboring European countries. Through this program, students have the opportunity to learn a completely different educational system and compare it to their own countries' one, become familiar with other cultures, broaden their horizons, meet people who would otherwise never get to know, become witnesses of different cultures and create new opportunities. The Erasmus program helps students become familiar with other learning processes and gain additional work experience within a different context. At the end of the program, there might be a number of students earning an academic and/or work position either at the graduate level or in their professional field. One of the main educational activities of the TEI of Thessaly is the Erasmus action, which offers the opportunity to students, who have completed at least the first year of their study, to attend part of their course work at an Institution in another country of the European inter-university cooperation. The experience of the Erasmus program is particularly important for intercultural and employment, leading to new perspectives for better and more stable jobs. An attempt to explore the views and concerns of students of the TEI of Thessaly, who benefited either by being moved to another country within the Erasmus program activities or interacted with students from other EU countries, is the focus of the present study.
\end{abstract}

Keywords : Erasmus Program, mobility, multiculturalism, intercultural, Europe

\section{Introduction}

In the global education, market is the most important asset of any democratic society. Europe is the "mother" of Universities concept and founded an educational system based on the supremacy of Western civilization. European governments have contributed to the development of public education. It is significant that during the twentieth century 
achieved significant growth in all levels of education (Xanthopoulos, 2002). The modern world is known for its multiculturalism, its constant changes in culture and the effects of accepting cultures in everyday level. Effects occur in the cultural life of the country, the education system, the religious sector and elsewhere. The term globalization is introduced for the first time since M. McLuhan (1968), who referred to the "Global Village", emphasizing internationalization, especially in the field economy and then the superstructure (Vasiliou et al, 2000).

In education, the impact of globalization is dependent on indirect attitudes that keep nations - states towards this. Globalization contributes to the development of ideas for the future and by the general educational policy contributes to the stabilization of democratic institutions in an environment that is constantly evolving. The educational systems of several states target to the orientation to modern technology and the fight against unemployment (Weaver, 2004).

According to the European Commissioner for Education, Culture, Multilingualism and Youth A. Vasiliou "The Erasmus ${ }^{1}$ program is one of the most successful in the EU: Is the best known and most popular program. Exchanges through the Erasmus program offer students the opportunity to improve their knowledge of foreign languages and develop skills such as adaptability, which in turn improves their job prospects.... In many countries, the demand for the program far exceeds the available resources. This is one reason why we plan to expand the opportunities for study and training abroad through our proposed new program for education, training and youth program Erasmus for all" (http://europa.eu/rapid/pressReleasesAction.do?-reference=IP/12/83\&format=HTML\&aged=) and mentioned that "Erasmus is one of the greatest successes of the EU. The latest figures speak for themselves: Erasmus is more popular than ever and I am committed to ensure more resources for the future. Studies or internships abroad open doors to personal growth and create employment opportunities. Therefore, we have a right to be ambitious when it comes to investing in our youth" (http://europa.eu/rapid/pressReleasesAction.do?reference=IP/11/675-\&format=HTML\&aged= O\&language=EL). The purpose of the program is to gain professional experience relevant to the subject of study, knowledge and understanding of economic and cultural conditions in other European countries and the acquaintance of the requirements of the European market.

This study will not deal with the procedural aspects of the program including the selection process for students, funding and more. The purpose of this paper is to highlight the practical implementation of the Erasmus program and its dimensions. Specifically, how useful it is, if it contributes to the development of students in finding employment within and outside the country of origin and whether it helps to multiculturalism and create a European identity for young people. The survey was based on reports in the Reports Studies and Practice of Erasmus students and interviews with students who participated in this program. The purpose of the program is to gain professional experience relevant to the subject of study, knowledge and understanding of economic and cultural conditions in other European countries and the acquaintance of the requirements of the European market.

In the current study we will define the key concepts associated directly or indirectly with the program. It will follow the presentation of the program from 1987 until today and then we will focus on the main answer research questions, based on the views expressed by students participating in the program and data relating to the participation of Greek students in the program. Then we present a survey conducted among the students of the Institute of Thessaly who took part in it. The paper concludes with a presentation of research results and conclusions.

\section{Literature review}

Education, in the broadest sense, includes all activities designed to influence in thought, character, and physical education of the individual. From a technical standpoint, the education acquired knowledge, skills, abilities and values. The training is based on specific methods (theoretical teaching, demonstration, assignments, practical training) in a specially designed program, with specific learning objectives and is delimited in time. Aims of education is the formation of character, which will help young people in interpersonal relationships, development of intelligence, equipping young people with the knowledge and skills according to their abilities to earn a life and contribute to further development of the national economy and end the effort to make new able to adapt to changing social and economic conditions (Aspridis, 2011; Chatzidimou, 2010; Bourandas et al, 2002; Werther et al, 1985).

The Erasmus program prefers multiculturalism and intercultural education. The term multiculturalism principle states that coexist in a society different social groups with different national - ethnic and cultural references. As a term used first and foremost in USA, Australia, England and Canada. Multiculturalism is often confronted in the assimilation of immigrants (for Equal Integration requires the new member to become similar and the values adopt majority) and social

${ }^{1}$ The acronym Erasmus is the analysis of the words EuRopean Community Action Scheme for the Mobility of University Students 
inclusion (equal access for minority groups to opportunities, goods and services enjoyed by the majority). Multiculturalism was adopted in various countries of the western world from 1970 onwards for different reasons, and often opposite to the actual fact of rapid ethnic, religious and cultural diversity of the population and while were formed as nations - countries with a single national identity in the 18th and 19th century. Due to the creation of nations - states is very difficult to set up a coherent multicultural society, especially in times of crisis, where weak social classes, are reducing the welfare state

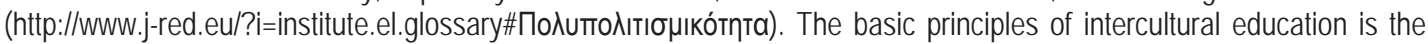
recognition of the cultures and their interaction, the value of cultural capital people from different cultural backgrounds, ensuring everyone's right to equal opportunities in education (http://www.j-red.eu/?i=institute.el.glossary

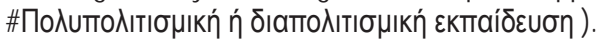

\section{The History of Erasmus Program}

The Action Plan was launched in 1976 under the name Short Study Visits (SSVs), Joint Studies Programs (JSPs). J. Delors accessed reactions of Ministers of Education and the Commission through the competent application of the European Council in London (5 - 06.12.1986) and from that moment began the Erasmus. The first period, the budget amounted to 85 million ECU, the second period (1990 - 1994) to 192 million ECU. In 1987 for the first time worked between higher education institutions in Europe for the first time a student exchange program which only his first year involved 3,244 students. In one of the most recognized programs of the EU until 2006 attended by more than 2,000,000 students from all over Europe, and the same year the program received 150,000 students. In 2012, the European Commission estimates that $3,000,000$ students to participate. Followed by other programs such as the Bologna Process (promoting mobility, recognition, joint degree programs, ECTS, DS), which also adopted 10 action lines, LLP and finally the Youth on the Move (Asderaki, et al, 2011; Dokou, 2007; Weidenfeld, 1997).

Of the total number of students receiving support under the Erasmus period 2009 - 2010, the 178,000 made part of their undergraduate program of study abroad at a university or other institution of higher education in one of the countries participating in the initiative Erasmus. The number of students who chose the feasibility study rose by $5,7 \%$ compared with the previous year. Internships in companies abroad by Erasmus was built in 2007 and is becoming increasingly popular. In 2009 - 2010, 35,000 students (the 1/6 of the total) chose this option. This is an increase of 17.3\% over the previous year. The average monthly Erasmus grant received by students decreased by about $7 \%$ to 254 million due to the increased number of students receiving support. The demand substantially exceeds availability of Erasmus in most participating countries. According to a survey conducted by the European Parliament, 2010 , found that only $24 \%$ of students not participating in Erasmus said they are not interested in study abroad program (http://europa.eu/rapid /pressReleasesAction.do?reference=-IP/11/675\&format=HTML\&aged=0\&language=EL).

Figure 1: Number of students ERASMUS annually [from 1987 - 88 to 2010 - 11]

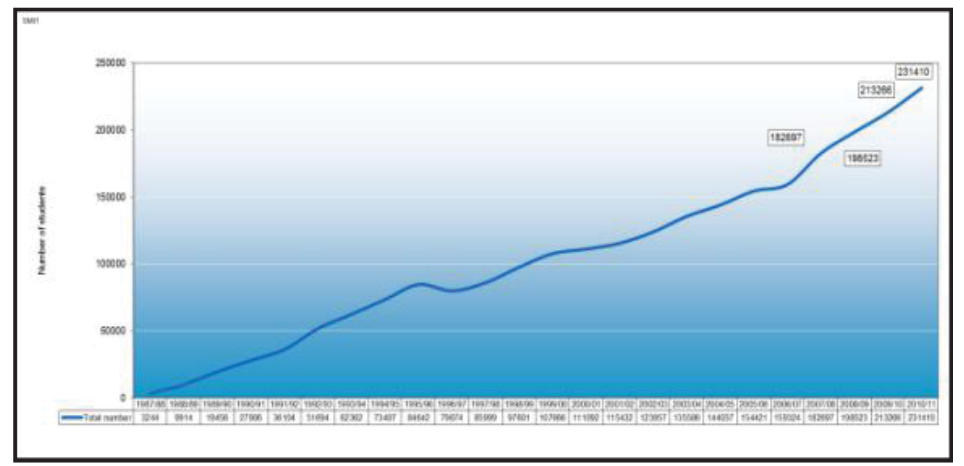

Source:http://europa.eu/rapid/pressReleasesAction.do?reference=MEMO/12/310\&format=HTML\&aged=0\&language=EL \&guilanguage=en

Figure 2: Student mobility Erasmus -Change in the number of students per sending country between $2009-10 \& 2010$ 11 


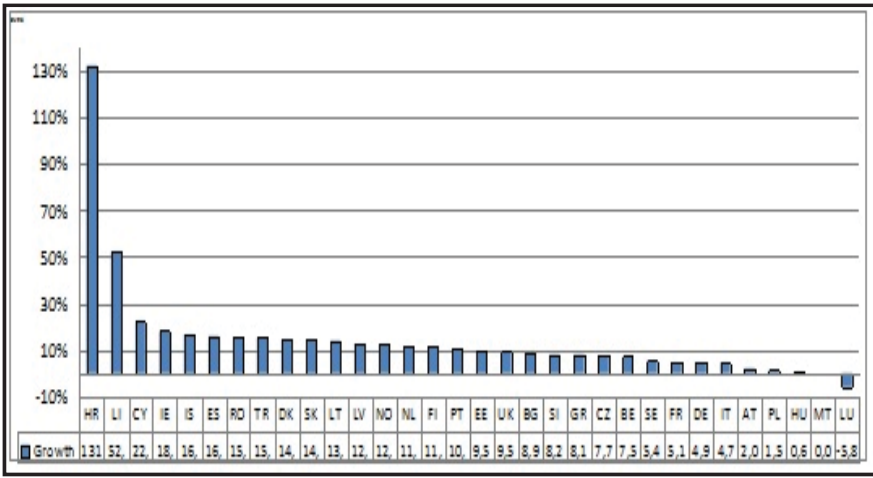

Source:http://europa.eu/rapid/pressReleasesAction.do?reference=MEMO/12/310\&format=HTML\&aged=0\&language=EL \&guiLanguage=en

Figure 3: Student mobility Erasmus -Average monthly EU level scholarships

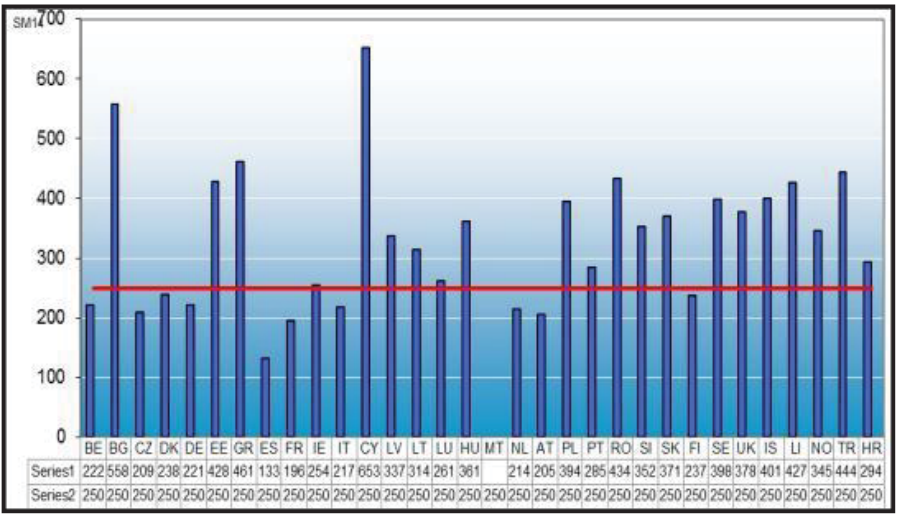

Source:http://europa.eu/rapid/pressReleasesAction.do?-reference=MEMO/12/310\&format=HTML\&aged=0\&language =EL\&guiLanguage=en

Figure 4: Number of Erasmus Intensive Language Courses from 2005 -2006 to 2009 - 2010

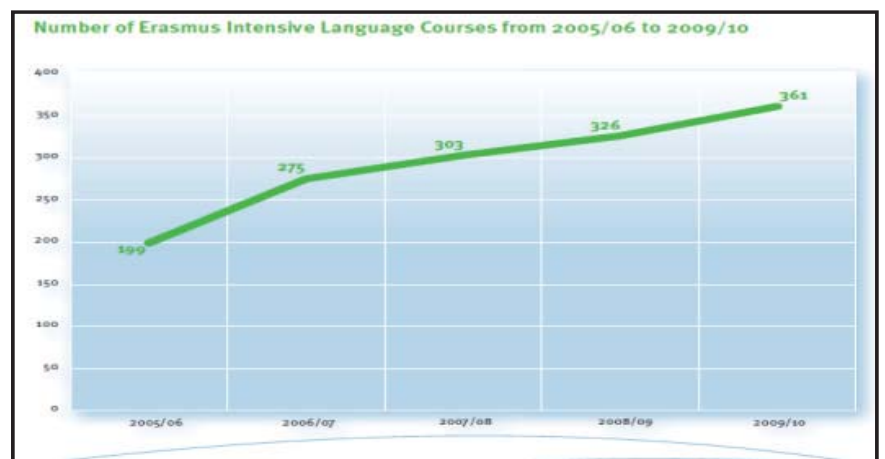

Source:http://europa.eu/rapid/pressReleasesAction.do?reference=MEMO/12/310\&format=HTML\&aged=0\&language=EL \&guiLanguage=en

The importance attributed to Erasmus of the EU, highlighted in Articles 165 to 166 of the Treaty on the Functioning of the EU More specifically, Article 165 states inter alia that "the EU action shall be aimed at: encouraging mobility of students 
and teachers, inter alia by encouraging the academic recognition of diplomas and periods of study, promoting cooperation between educational institutions, encouraging the development of youth exchanges and youth workers, and encourage the participation of young people in democratic life in Europe" (Moussis, 2011; Nugent, 2003).

Table 1: The evolution of Erasmus program

\begin{tabular}{|c|c|c|}
\hline A/A & Year & Event \\
\hline 1. & 1976 & The program begins with the name Short Study Visits (SSVs), Joint Studies Programmes (JSPS) \\
\hline 2. & $5-6 / 12 / 1986$ & $\begin{array}{l}\text { J. Delors accessed reactions of Ministers of Education and the Commission through the } \\
\text { competent application of the European Council in London }\end{array}$ \\
\hline 3. & $17 / 6 / 1987$ & $\begin{array}{l}\text { The Erasmus program starts with the first exchange of nearly } 3.000 \text { students from } 11 \text { countries - } \\
\text { EU members (Belgium, Denmark, Germany, Greece, France, Ireland, Italy, Netherlands, Portugal, } \\
\text { Spain and United Kingdom) }\end{array}$ \\
\hline 4. & 1988 & Integration of Luxembourg in the program \\
\hline 5. & 1992 & Six countries included in the program (Austria, Finland, Iceland, Norway, Sweden and Switzerland) \\
\hline 6. & 1994 & Accession of Liechtenstein to the program \\
\hline 7. & 1996 & $\begin{array}{l}\text { i. Introduction of intensive courses of Erasmus } \\
\text { ii. Join TEl of Thessaly Socrates program }\end{array}$ \\
\hline 8. & 1997 & Establishment of the Erasmus exchange teaching staff \\
\hline 9. & 1998 & $\begin{array}{l}\text { i. Sorbonne Declaration on the harmonization of higher education. } \\
\text { ii. Six countries included in the program (Cyprus, Czech Republic, Hungary, Poland, Romania and } \\
\text { Slovakia) }\end{array}$ \\
\hline 10. & 1999 & Five new countries join the program (Bulgaria, Estonia, Latvia, Lithuania and Slovenia) \\
\hline 11. & 2000 & Accession of Malta to the program \\
\hline 12. & 2001 & Prague Declaration \\
\hline 13. & 2002 & Celebration millionth student \\
\hline 14. & 2003 & Establish the Erasmus University Charter \\
\hline 15. & 2004 & Turkey's membership in the program \\
\hline 16. & 2005 & $\begin{array}{l}\text { Summit Bergen, } 19 \text { - } 20 \text { May } 2005 \text { - set targets for the London summit in 2007, including the } \\
\text { application of criteria and guidelines for the reporting of ENQA (European Association for Quality } \\
\text { Assurance in Higher Education) }\end{array}$ \\
\hline 17. & 2007 & Integration of Lifelong Learning \\
\hline 18. & 2009 & Celebrating completion 2.000 .000 students and Croatia in the program \\
\hline 19. & $2009-2010$ & 3.000 institutions cooperating in the program \\
\hline 20. & 2011 & $\begin{array}{l}\text { i. Re-integration of Switzerland in the program. } 33 \text { countries participate in the program } \\
\text { ii. Enactment of Law } 4009 / 2011 \text { with reports on student mobility }\end{array}$ \\
\hline 21. & $2012-2013$ & Expected completion 3.000 .000 students in the program \\
\hline 22. & 2014 & Start the new Erasmus program for all \\
\hline
\end{tabular}

Source : E.U., (2012), Erasmus. Changes lives, opens horizons for 25 years, Belgium

The number of Erasmus students increased in almost all countries. The largest increase occurred in the outgoing students Croatia (132\%), Liechtenstein (52\%) and Cyprus (22\%). In 19 countries, an increase higher than the average was 8.5\%. In Luxembourg, the number of Erasmus students declined (-5.8\%). However, it remains the country sends abroad the largest number of students as a percentage of the national student population. Spain has sent the most students, followed by France and Germany. Spain is the country that has received the most students, followed by France, Germany and UK (http://europa.eu/rapid/pressReleasesAction.-do?reference=MEMO/12/310\&format $=$ HTML\&aged $=0 \&$ language $=E L \&$ guilanguage $=e n) .^{2}$

According to the Commissioner, in the period 2014 - 2020 will implement the "Erasmus for all" which will bring together all existing EU programs The Commission has proposed a budget increase to around 5 million over the next seven years. The program will be open to countries outside the EU The proposal is currently being discussed and negotiated with the Member States and the European Parliament (Vasiliou, 2012).The current financial period (2007 2013), the EU spent 3.1 billion Euros for the program Erasmus. In 2010 - 2011 the total budget amounted to about 460 million $€$, of which $€ 435$ million was spent to support mobility. The largest part of the budget of the Erasmus program is

${ }^{2}$ For the eligibility criteria for students of Erasmus, the website http://compus.uom.gr/erasmus/files/file/-xartis_foititi_erasmus.pdf. 
managed by the National Agencies in the participating countries. Nearly $90 \%$ of the budget available for the Erasmus program for mobility of students and staff. The Erasmus also supports multilateral projects and networks of around $4 \%$ of the budget. Are managed centrally by the Executive Agency Education, Audiovisual and Culture (EACEA) in Brussels (http://europa.eu/rapid/pressReleasesAction.do?reference=MEMO/12/310\&format=HTML\&aged=0\&language=EL\&guiLa nguage $=e n$, accessed on 7/8/2012; Kaminara,2011).

J. Figel', Former European Commissioner for Education, Training, Culture and Youth, said "a growing number of European student is able to participate in exchanges Erasmus. The fact that the program has helped 2 million students to go abroad for studies and placements since its launch makes Erasmus a European success story. Research clearly shows that not only themselves but also the movers and educational institutions and society as a whole greatly benefit from such transnational mobility. Now we would like to build on the success of Erasmus and offer such opportunities to all young people who want to go abroad for learning purposes. For this purpose, we have recently opened a public consultation on the best strategy to achieve this goal" (http://www.panteion.gr/index.php/anakoinoseis-menu/586-erasmus-).

U. Eco forms a different approach as Erasmus, which may result in the ideal cultural assimilation and the formation of a European identity. Emphasizes characteristics that he mentioned "sexual revolution in European student exchange program Erasmus", because he created the first generation of Europeans : A young Catalan knows a Flemish, fall in love, marry and become Europeans, like their children. It also emphasizes the need for this program, not only from the student community, but also from the whole society, stating that "the idea of the program should be mandatory, not only for students but also for Europe ... employees. What they actually mean is that they should live in different European countries should be communicate each other ... Europe is the continent that united many different identities without, however, to confuse" because in this way we will deal with the fact that no European culture. He mentioned that "European culture is widespread but shallow.... This must change before the crisis managed to strip Europe of everything" (http://www.tovima.gr/world/article/?aid=440512).

\section{Erasmus in the words of students}

For many European students, the Erasmus Program is their first time living and studying abroad. Hence, it has become a cultural phenomenon and is very popular among European students. ${ }^{3}$ The Program fosters not only learning and understanding of the host country, but also a sense of community among students from different countries and it can be hard to know what one might expect. The Erasmus experience is considered both a time for learning as well as a chance to socialize (http://erasmus.com/en/erasmus-blog/erasmus-scholarships/erasmus-programme-81224). Student mobility contributes to personal development and the development of social skills, labor mobility and knowledge and develop the market of educational services. Contributes to the creation of a European identity, it helps create an open democratic and tolerant society, creates a creative, multicultural environment (http://compus.uom.gr/-erasmus/?q=el/general).

As reported by the students who participated in the program, the experience from the Erasmus compares to study a single trip since gave them the opportunity to develop a true European consciousness (Benhold, 2005). Erasmus students are familiar with a foreign language (Charalampakis, 2002) and gain valuable skills for the labor market, such as adaptability and awareness in different cultures. Students gain European dimension of their studies through teaching by teachers with different education and culture, different teaching methodology and subject, the study of foreign literature and the possibility of contact and explore new topics. Students learn faster a foreign language, exploring the prospects for postgraduate studies abroad and then compare the education offered by this university of origin (http://issuu.com/iserviceeuropa/docs/eacerasmus25_brochure-_120420_el_ipad?mode=window\&viewMode=double Page).

Here are some aspects of European students who participated in the program. "I realized that the experience made a whole new person of me and that I would never look at the world and Europe, my home, as I did before", "Erasmus life for me is about opportunities. Every opportunity I had, I took it and I thank Erasmus for it", "It is true - when you're in Erasmus, you find out a lot about yourself", "Erasmus is a lot more than a studying experience. For me it is a way to look at the world with new eyes, to feel and discover new emotions and learn what is not written in the textbooks,. "If I look at my experience from a distance, I can say that I would definitely do it again, and that apart from (or maybe

${ }^{3}$ The importance of the program and especially of civilization, becoming in any way in European culture. For example, in the French film "The spannish inn» (L'Auberge espagnole), 2002, describes the adventures of a student studying in Barcelona on Erasmus, http://www.imdb.com/title/tt0283900/. 
because of) minor problems along the way, this semester has made me a stronger and more enthusiastic person" (E.C., 2007; http://ec.europa.eu/education/lifelong-learning-programme/doc80_en.htm; http://news.-kathimerini.gr/4dcgi/_w _articles_ell_100050_07/07/2012_488231).

Many are the views expressed by the Greek students who participated in the program. Student at the University of Crete, said changed her life. He stressed that "Erasmus gave me the opportunity to come into contact not only with the French culture but at the same time and in many different cultures. And that's why we stayed with students from around the world and constantly organizes trips to other European countries". Another student argued that "contact with citizens of other countries makes you take a breath and seek solutions as a world citizen and not as a citizen of a country isolated" (http://www.tovima.gr/relatedarticles/-article/?aid=103297).

Student, who made the practice exercise for the OECD, through the program, said that "one of the greatest benefits of the practice abroad is the contact with people who have different approaches in a multidisciplinary level in the work environment. Having taken a small but significant bit of the multicultural culture of the people of France, on an interpersonal level, I think we need to realize that each student extroversion on mobility has too many fruits to offer, I recommend it unreservedly". Student of the Agricultural University mentioned that "I learned many things on scientific research, I gained significant professional experience, working with serious and eminent scientists and finally, collaboration and contact with students from different countries. I hope others follow this path" (http://www.european.aua.gr/socempeir.htm). ${ }^{4}$

Other students said that "Erasmus is the best opportunity for a student to get acquainted with the easiest and most fun way, a new country, a new city, other students from every corner of the earth, but a university education different from that which has been learned his country". "Erasmus go to meet people, to see how the heck the school in another country does, experience the culture of this country, to improve your knowledge on foreign language", "the Erasmus looks like a break from the routine student. Freshman place, another university, new people, new ways. Means using language 24/7, which in turn means that we can express all your thoughts, needs, opinions, even the weaker moments you (from illness to sleep) in it" (http://www.in2life.gr/everyday/modernlife/articles/233505/article.aspx).

Normal result of this program was the creation of the Erasmus Student Network (ESN), which was founded in 1980 and is a European student organization that aims to support and contribute to the development of the exchange students. The network works to improve social inclusion and practice of student exchange and represents the needs and expectations of exchange students at the local, national and international level (Kraklewska et al, 2005; http://www.esn.org). Unfortunately, the program has its negative consequences, because the area of higher education is a breeding ground for abuse regulations were designed to expand the educational opportunities of students in EU universities For example, while the program was established by several European countries to exchange students that they have experience of life and education outside their home countries, occurred where Greek students in foreign universities coming to Greece under the Erasmus program and enrolled for at least one year in Greek institutions (http://e-thessalia.gr/?p=22831).

\section{The Erasmus program in Greece and the T.E.I of Thessaly}

For Greece, program has become particularly important because of the economic crisis many young people seeking their way to Europe through this. In 2012, Greece received $2.1 €$ million for internship programs through Erasmus. According to the data available in the internship program involved a total of 1,379 Greek students. In 2011 the total outgoing Greek students for studies and placements amounted to 3,437, and last year was 3,179. 30,732 businesses across Europe accept students for internship of which $45.4 \%$ are small and medium in $33.8 \%$ and $20.8 \%$ large. 2.308 Greeks have visited another EU country to attend a semester. Greek students who benefited from the new institution was the last year 160 people (http://ec.europa.eu/education/erasmus/doc/stat/1011/countries/greece_en.pdf).

Table 2: Number of Erasmus students

\begin{tabular}{l|l|l} 
Year & Entrants & Outgoings
\end{tabular}

${ }^{4}$ E.U., (2012), Erasmus. Changes lives, opens horizons for 25 years, Belgium [in Greek]. 


\begin{tabular}{|c|c|c|}
\hline $\mathbf{2 0 0 0 - 2 0 0 1}$ & 1.302 & 1.868 \\
\hline $\mathbf{2 0 0 1 - 2 0 0 2}$ & 1.413 & 1.974 \\
\hline $\mathbf{2 0 0 2} \mathbf{- 2 0 0 3}$ & 1.545 & 2.115 \\
\hline $\mathbf{2 0 0 3 - 2 0 0 4}$ & 1.595 & 2.385 \\
\hline $\mathbf{2 0 0 4 - 2 0 0 5}$ & 1.658 & 2.491 \\
\hline $\mathbf{2 0 0 5 - 2 0 0 6}$ & 1.903 & 2.714 \\
\hline $\mathbf{2 0 0 6 - 2 0 0 7}$ & 1.841 & 2.465 \\
\hline $\mathbf{2 0 0 7 - 2 0 0 8}$ & 2.299 & 2.468 \\
\hline $\mathbf{2 0 0 8 - 2 0 0 9}$ & 2.849 & 3.029 \\
\hline $\mathbf{2 0 0 9 - 2 0 1 0}$ & 2.983 & 3.179 \\
\hline $\mathbf{2 0 1 0 - 2 0 1 1}$ & 2.860 & 3.437 \\
\hline Total & 22.246 & 28.125 \\
\hline
\end{tabular}

Source: http://ec.europa.eu/education/erasmus/doc/stat/1011/countries/greece_en.pdf,

Table 3: Number of students held internships

\begin{tabular}{|c|c|c|}
\hline Year & Entrants & Outgoings \\
\hline $\mathbf{2 0 0 7 - 2 0 0 8}$ & 488 & 160 \\
\hline $\mathbf{2 0 0 8 - 2 0 0 9}$ & 903 & 292 \\
\hline $\mathbf{2 0 0 9 - 2 0 1 0}$ & 924 & 389 \\
\hline $\mathbf{2 0 1 0 - 2 0 1 1}$ & 879 & 538 \\
\hline Total & 3.194 & 1.379 \\
\hline
\end{tabular}

Source: http://ec.europa.eu/education/erasmus/doc/stat/1011/countries/greece_en.pdf,

Figure 5: The reasons for choosing to stay Greek students abroad

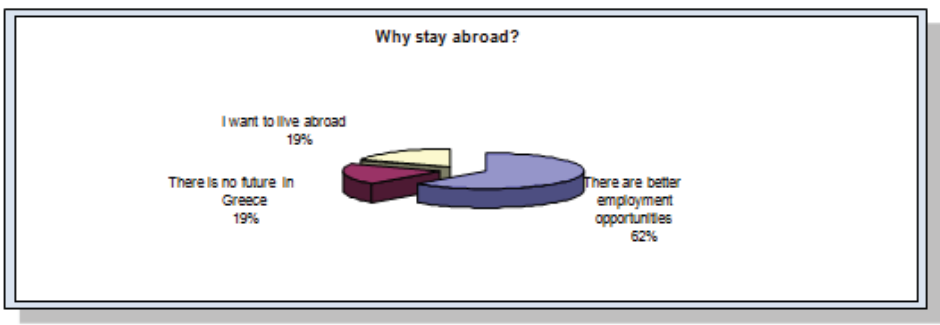

Source: Asderaki et al, 2011

In the first five positions of the institutions that send students abroad is the University of Athens, in concrete the Economic University, the Aristotle University of Thessaloniki, and two Colleges. Greek students respectively go to Spain, France, Germany, Italy and the UK (data for SA from 2010 to 2011 http://ec.europa.eu/education/erasmus /doc/stat/1011/countries/greece_en.pdf).

TEI of Thessaly was established in 1983 (L. 1404/1983), when abolished by then operating Centers of Higher Technical \& Vocational Education, and established the level of Higher Education, which joined the Higher Education Institutions. Therefore, TEl (according to L. 2916/2001) enrolled in Higher Education.

The TEl of Thessaly is involved in the implementation of the Socrates program from 1996 until today, and with the completion of the second phase of the program (01/01/2000 - 31/12/2006), approved the participation of the institution in the University Charter Erasmus. Through the Erasmus given the opportunity to students who have completed at least the first year of study, attend part of their studies in another country Institution in European interuniversity cooperation. The study period abroad may include coursework, internships or thesis preparation and is fully recognized by the return of the student (http://www.teilar.gr/eu/index_gr.php). The program gives students the opportunity to experience life in another culture, studying in a different system of Higher Education. The TEI Thesssaly has many partnerships with higher 
education institutions from France, Germany, Finland, Czech Republic, Netherlands, Bulgaria, Portugal, Italy, Cyprus, Poland, Denmark, Hungary and Spain (http://www.teilar.gr/eu/index_gr.php). ${ }^{5}$

According to data available from the TEl of Thessaly sent thirty-two (32) students in various institutions abroad for study, both the 2009 - 2010 and from 2010 to 2011. Moreover, for practice departed two (2) students in 2009 - 2010 and nine (9) students in the period from 2010 to 2011. Incoming students for the last amounted to fifteen (15) from different EU countries. Finally, TEI has social policy because two (2) students participating in the program are from economically vulnerable and one (1) with severe disabilities (Seminar, 2011).

Figure 6: Students participate in Erasmus program (2007-2008 / 2011 - 2012)

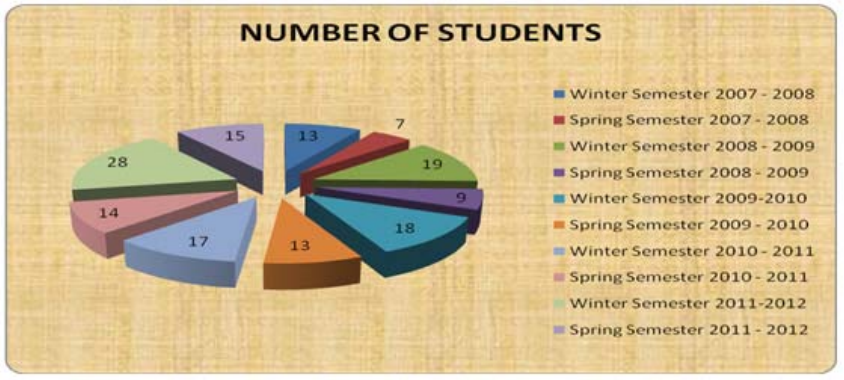

\section{Source : European Programs Office TEl of Thessaly}

\section{The research methodology}

The research methodology includes qualitative and quantitative approaches and tries to gather accurate information about social phenomena. Quantitative methods focus on numerical data and statistical comparisons, the measurement of theoretical concepts using tools such as standardized questionnaire. Qualitative methods are essential tools in the analysis of quantitative data and to formulate new hypotheses. Qualitative research focuses on the evolution of social phenomena, the processes by which we develop specific social situations. The combined and complementary use of quantitative and qualitative methods is the most effective methodological approach for a complete description and explanation of the dimensions of social reality (Saunders et al, 2009; Dawson, 2009; Paraskevopoulou-Kollia, 2008).

The interview is a key element of qualitative research and is not a simple formality. Those called to overcome the researcher is the reluctance and fear in the underlying communication layer. The interview goes beyond the walls that hinder effective dialogue, to bring about the approach of true reality. In unstructured discussion is taking place is in a sense free, but that freedom is related to the nature of the discussion, the matter is under investigation and the extent of building questions. The interviewer is the one who shows understanding what this respondent and helps to express interpret what he says and should be aware of psychology (Saunders et al, 2009; Dawson, 2009; ParaskevopoulouKollia, 2008).

In the questionnaire we used two kinds of questions or closed questions with specific answers questions and open questions. In open questions the respondent is asked to give his answer the way he wants. Open-ended questions allow the interviewee freedom of expression and do not provide any answers. In the closed-ended questions the answers are predetermined by the researcher. The default answers may be limited in the choice between 'Yes' or 'No' to include a whole range of alternative answers. Specifically, the advantages are as the respondent answers to written questions, can be affected by fluctuations in the occasional voice of the researcher, mistakes made in the researcher's effort to facilitate the response to clarification, the questionnaire allows for greater standardization in the wording of questions contributing thus the reliability of the data will come from this, it can be used in large numbers of people with ease, and is economical method. Disadvantages are the low percentage of questionnaires returned to the researcher. Also, it is assumed that the person who completed the questionnaire was not influenced by any third party, it is not certain that all questions were clear to all participants (Paraskevopoulos, 1993). 
The survey was based on the reports of study, relating the experience gained by the students of Erasmus, on the basis of the questionnaire submitted to the Office of the Institute of European Programs Thessaly with students who attended the Erasmus program in recent years. The interviews were structured and had little time to complete the interview. The aim of the research is the information gathered will be used to better prepare students who intend to move in future centuries as the continuous improvement of the program.The research objectives are specific, we know in advance the survey population. The questionnaire was administered immediately after the return of students from abroad the questions are in such series that progresses to complete them in a natural and logical way. Finally, the questionnaire did not have a large area and there are specific instructions for their completion. With the initiation of the investigation amounted files (handwritten and electronic) for the collection, collation and analysis of data. The concentration of the questionnaires, the entry of data (quantitative and qualitative), together with the SPSS program.

Our goal is the information and the conclusions of this study be used to best prepare students who intend to move in the future, as well as the continuous improvement of the program and to find the reasons why the students of TEI of Thessaly wish to participate in this program. The nature of this study highlights a number of barriers to the accuracy of data collected and the process to achieve the research objectives. One limitation may be the fact of ignorance of the concepts of correlation and is an issue that is still in its infancy in Greece. A second limitation is the limited interest of students for participation in the program.

\section{Presentation of research}

Figure 7: The participants per age group

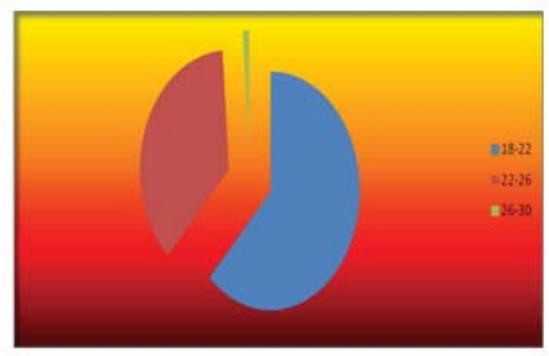

Figure 8: The participants per male

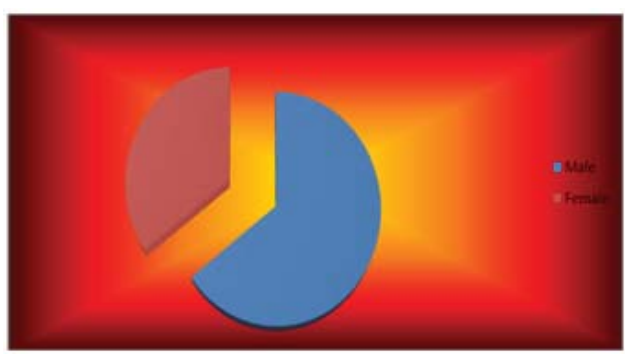

A total of 88 completed questionnaires students participating in the program. Of these, 54 belong to the 18-22 age group, 32 in the group 22 to 26 and 2 over 26 years (Figure 7). Participants were 57 men and 31 women (Figure 8).

Figure 9: Join students per semester 


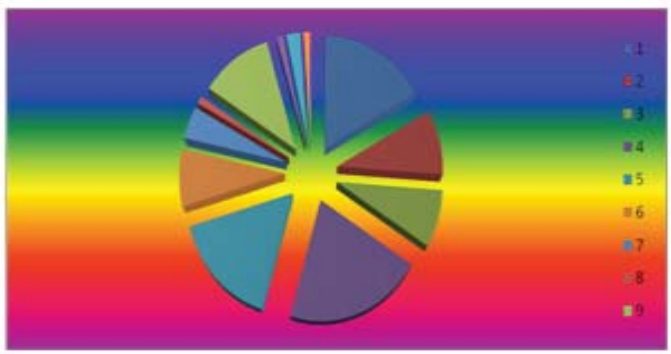

Figure 10 : The reasons for student participation in the Erasmus program

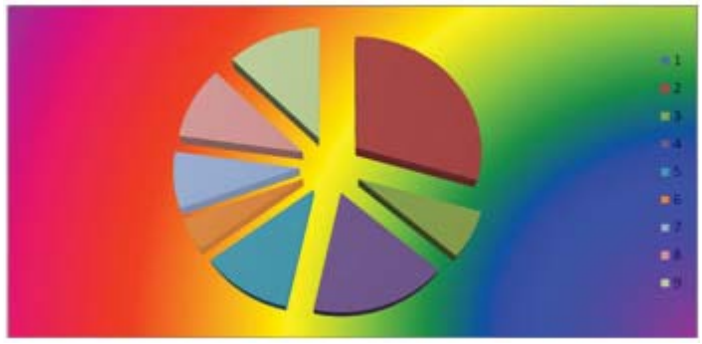

According to the previous diagram 15 students were from the 10th semester, 18 of the 8th semester, 14 of the 6th semester and 10 of the 9th semester. The other students are allocated to the remaining semesters, with less coming from the second half, only 1 and more, 9 of the 10th semester. According to the responses of the 26 participants were in the program for academic reasons, 15 to create friendships, multicultural interests 6,4 to experience a new environment, 6 to gain experience from Europe, 11 to learn a foreign language, 10 to gain specialized knowledge in management and finally 9 to feel independent from his family and other environment.

Figures 11a \& 11b : The personal benefits of students from the Erasmus gender
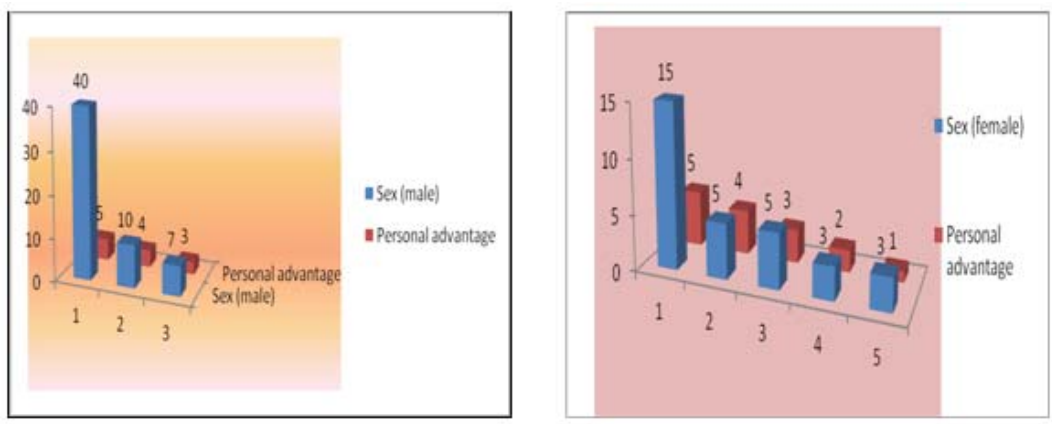

The male students who participated in the program showed that gained many significant personal benefits from their participation in it. One student replied that he was not satisfied with it. Unlike some of the students who participated said they did not obtain significant benefits from their participation in this.

Figures 12a \& 12b: The reasons students attend the Erasmus gender 

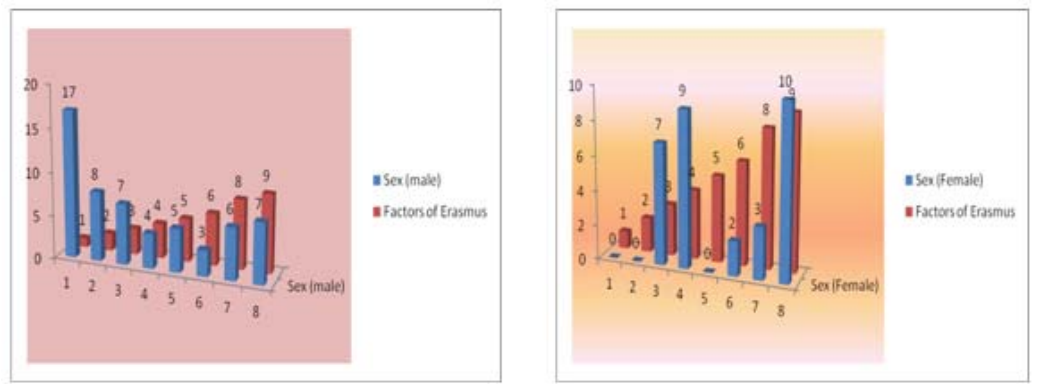

The male students who responded highlighted as the most important factor in the academic aspect of Erasmus followed multiculturalism, acquaintances and independence. From their side, students highlighted the main factors contributing to their independence, followed by training in a foreign language and stay in another country.

Figures 13a \& 13b: The personal experiences of the students from the Erasmus gender
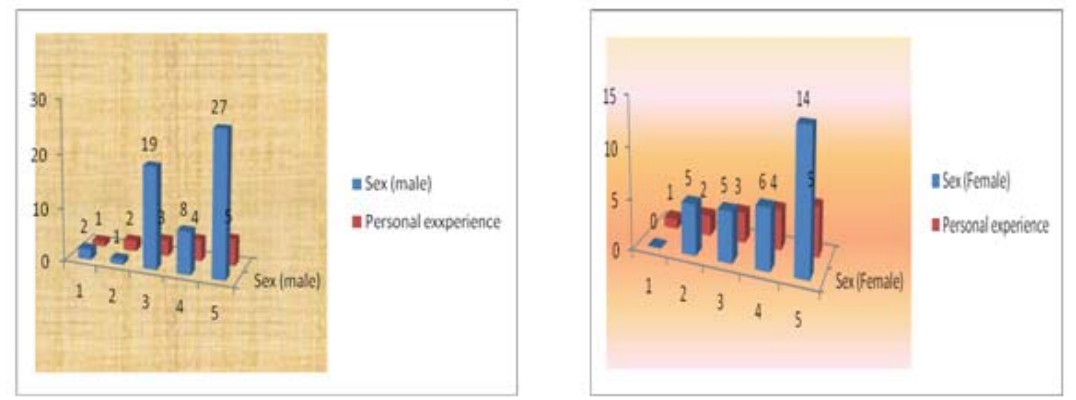

Students highlighted as the main experience self-awareness gained from their participation in the program and then their independence and confidence. On the other hand the students highlighted the self-awareness and the rest followed, with approximately the same number and with the exception of intercultural knowledge not answered any.

Figures 14a \& 4b: The most important aspects of participation in Erasmus gender
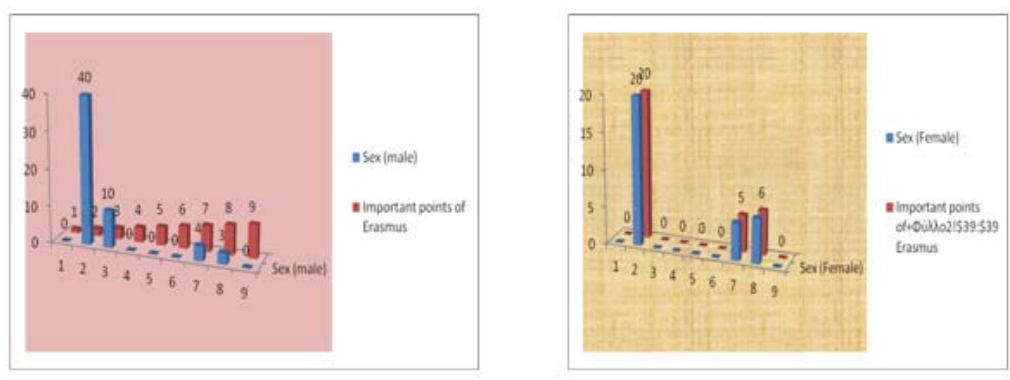

Students highlighted as the most important factor of program participation multiculturalism, while students highlighted gaining experience and independence.

Figures 15a \& 15b: Personal benefits from participation in the Erasmus program with age 

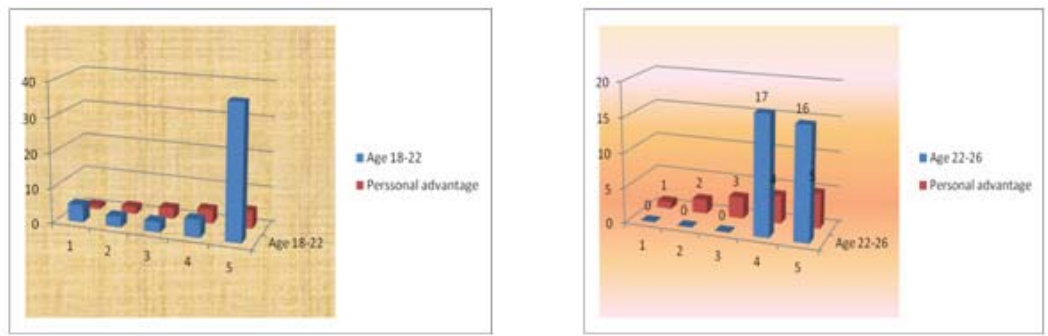

By age group not studied this class of 26-30, because we just had a completed questionnaire. From the questionnaires we conclude that most students who participated in either age 18-22 or the next class was very satisfied with their participation in the program.

Figures 16a \& 16b: The experience gained from participation in the Erasmus program with age
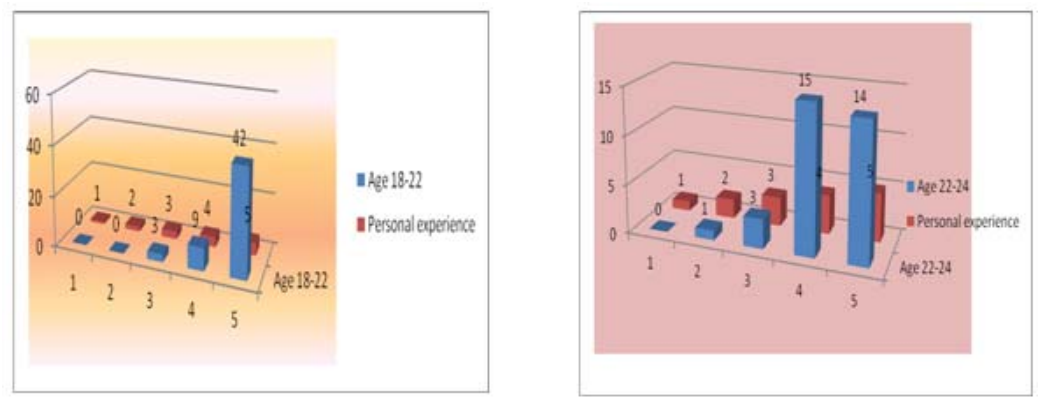

From the responses we conclude that most students who participated in either age 18-22 or the next category and gained many important experiences from the program.

Figures 17a \& 17b: What aspects of the ERASMUS program as being particularly significant gender
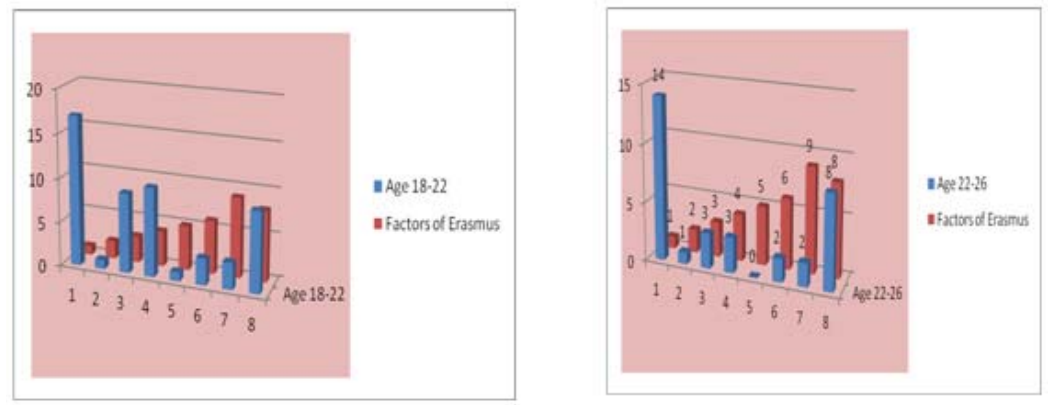

Students in the 18-22 age revealed as most important aspects of the Erasmus program their personal independence, training in a foreign language, academics and making friends. The students of the next age group highlighted the academics, personal autonomy / independence and finally stay in a foreign country and experience gained from staying there.

Figures 18a \& 18b: The most important aspects of participation in Erasmus gender 

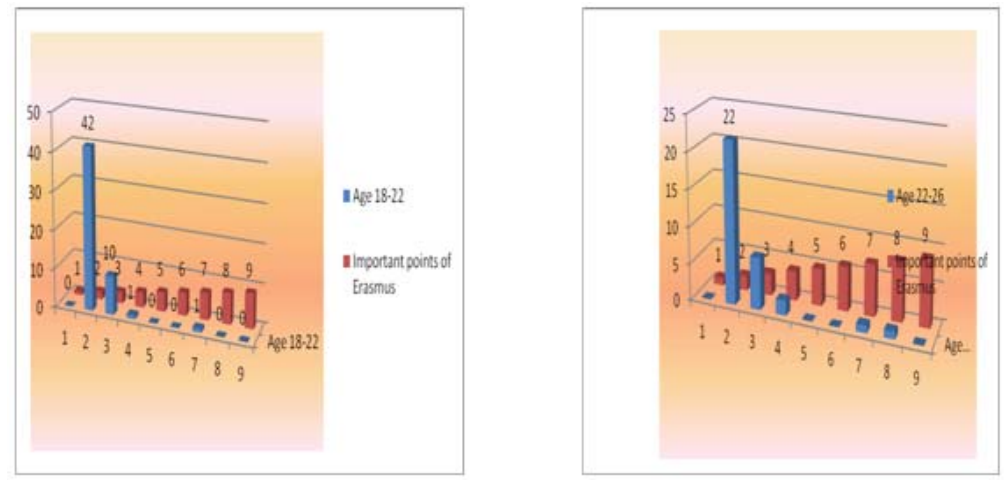

Both age groups highlighted as the most important element of their participation in the program to get acquainted with the culture of a foreign country and getting to know the country.

The interviewers revealed that students who participated in this project was not just satisfied but delighted. Experienced a new system of education and acquired significant knowledge about the object of study. Experienced new cultures they came into contact with new people and experienced the concept of multiculturalism and interculturalism. Saw it as a life experience.

\section{Conclusions}

Finally answered the questionnaire 88 students participating in the program. Participants were 57 men and 31 women were mainly students from the third $C$ and above. Most students who responded to the questionnaire said they participated mainly for academic reasons and then for reasons multicultural and gain new experiences. Students who responded revealed that the most important motivation for their participation in the program Academic aspect of Erasmus and then multiculturalism. Unlike the students highlighted as main factor independence and followed by training in a foreign language and stay in another country. Students in the 18-22 age revealed as most important aspects of the Erasmus program their personal independence, training in a foreign language, academic attitude and making friends. The students of the next age group highlighted the academic attitude, personal autonomy / independence and finally stay in a foreign country and experience gained from staying there.

Erasmus is able to contribute to improving the quality of education in our country. Let us remember, to better understand the importance of the words of former President K. Stefanopoulos when stressed that the basis of the progress of a country lies in education. .... requested the development of a sense of duty, the doctrine of social solidarity as a way to facilitate the betterment of all life, the cultivation of aesthetic kids to grow up to avoid acts that deface our country, strengthening the hard work and the suggestion the value of the offer' (Stefanopoulos, 2003). Information about these programs will cover the significant ignorance that exists and occurs both among students and professional bodies and companies in our country. For young students to participate in the Erasmus program gives them the opportunity to show off their skills, to deepen the scientific knowledge to develop professionally and learn new cultures (Damoulianou, 2012).

The study of the literature revealed that the Erasmus students gain more experience in the field of culture and multiculturalism, most students know the value of the program because have good information, and are interested in what they can gain new experiences and study abroad. However participation in the program is unsatisfactory and end the program helps them to improve their knowledge in a foreign language, discover new cultures, to become independent and gain new experiences (Alijošiūt et al, ny). The number of young Europeans study will work and will fall in love all over Europe growing. These young people did not grow up with the limitations of national consciousness grew by previous generations. On the contrary. Speak several languages, have multicultural awareness and feel Europeans. This is the generation that shaped and formed thanks to Erasmus.

Lifelong learning is essential for the competitiveness of the knowledge economy. Applies to all levels of education and training for all ages. The various programs such as Erasmus, here in after together all under the auspices of the program for lifelong education and training contribute to achieving these goals. Europe is experiencing one of the most 
critical periods in its history. The consequences of the crisis is evident. Investing in education and culture lays the groundwork for long-term benefits, which should not be forgottenn (Kalerade, 2011; Pasias et al, 2005).

From another point of view multiculturalism, which is required by the youth of Europe today, as to have a common identity. International education is essential for the most talented young people and European companies attract executives from across the continent. Stefan Wolff, Professor of political science at the University of Bath, calls these new "Generation Erasmus". When this generation take over the coming decades, could be made a profound cultural intersection, says Wolff. Provides that "for the first time in history we see the seeds of a true European identity. At 15, 20 or 25 years, Europe will be ruled by leaders with a completely different view of the socialization of today. I am optimistic that in future there will be much less interstate frictions and much greater consistency between the states - members of what we can imagine today". Wolff states that Europe will be headed by leaders with "less ethnic strife, fewer conflicts with Brussels and more unity in policy of the EU" (Kathimerini, 2005a; Kathimerini, 2005b).

\section{References}

Alijošiūt, M., Balevičiūt, V., Grabauskait G., kaı Juškevičiūt, G., (ny). «Students; interest in the Erasmus studies»,in the website https://ojs.kauko.It/index.php/stmd/article/download/176/170.

Asderaki, F. Galanakis, K.., and Mavrogiorgis E., (2011). Lecture on «Erasmus: Historical Background and contribution to the internationalization of Higher Education" website http://www.uoc.gr/intrel/MP_-Introduction.ppt, accessed on 10/8/2012 [in Greek].

Aspridis, G. (2011). "The training and development of civil servants', Journal of Management Science, Vol. 17 [in Greek].

Bernhold K., (2005). "Quietly sprouting: A European identity", International Herald Tribune, in the website http://www.iht.com/articles/2005/04/26/news/enlarge2.php.

Bourandas, D., and Papalexandri, N. (2002). Human Resource Management, Athens : Benos [in Greek].

Charalampakis, Ch. (2002). "The future of the Greek language", Liberals Focus, Vol 11 (52-67) [in Greek].

Damoulianou, Ch., (2012). "Opportunity practice another country in Europe", Kathimerini, 2/9/2012 [in Greek].

Dawson, C., (2009). Introduction to research methods : A practical guide for anyone undertaking a research project. 4th ed. Oxford: How to Books Ltd.

Dokou, M. (2007). "The influence of the EU in the administration of education", Proceedings of the first Congress of Administrative Sciences, Thessaloniki [in Greek].

Eco, U. (2012). «This identity is reinforced by the culture - The great semiologist considers that the Erasmus program is «sexual revolution», Vima, 27/01/2012 [in Greek].

E.U., Greece, Study on Mobility Developments in School Education, Vocational Education and Training, Adult Education and Youth exchanges, http://europa.eu/about eu/countries/membercountries/greece/-index_en.htm.

European Commission, (2012). Erasmus. Changes lives, opens horizons for 25 years, Belgium [in Greek].

European Communities, (2007). Erasmus success stories - Europe creates opportunities, Luxembourg.

Hatzidimos, Ch. M., (2010), Introduction to Education. Athens : Kyriakidis [in Greek].

Kathimerini, (2005a). «The Europe's generation- Erasmus». Blastainoun now the seeds of a true common European identity", International Herald Tribune, 30/4/2005 [in Greek].

Kathimerini,(2005b). "The younger generation gives identity in the new Europe. Changes in education and everyday life lead to a common European consciousness", International Herald Tribune, 30/4/2005 [in Greek].

Kalerante, E., (2011). «Public places knowledge "in education or lifelong education as an economic treaty" proposal at the Conference on "Institutions in Greece Valuation of the post-season a contradictory" T.E.I. of Kalamata, 4-6 November [in Greek].

Kaminara, A., (2011). Speaking at an event organized by the CUT on January 30, at the main auditorium of the university in Limassol, in the website http://ec.europa.eu/cyprus/news/speeches/archives-/20120208_speech_el.htm [in Greek].

Kraklewska, E., and Krupnik, S., (2005). The experience of studying abroad for exchange students in Europe - Erasmus Student Network Survey in partnership with Petrus Communications, Paris.

Mousis, N., (2011). EU - Law, politics, economics, 13th edition, Athens : Papazisis [in Greek].

Nugent, N., (2003). Politics and Government in the EU, Athens : Savvalas [in Greek].

Papadimitriou, Z., (1997). "Racism and European culture", Greek Journal of Political Science, vol. 10 [in Greek].

Paraskevopoulos, I.. (1993), Methodology of scientific research, Athens : the same [in Greek].

Paraskevopoulou-Kollia, E.-A.. (2008). «Methodology of qualitative research in social sciences and interviews», Open Education - The Journal for Open and Distance Education and Educational Technology, Vol. 4, N.1, Section 1 [in Greek].

Pasias, G., and Flouris, G.,(2005). "The 'Europe of Knowledge' as a challenge and as a representation ton of power relations - European knowledge in educational contexts" in Gravaris, D. and Papadakis, N., (ed.), Education and educational policy - between state and market, Athens: Savalas [in Greek].

Saunders, M., Lewis, P. and Thornhill, A., (2009), Research methods for business students. 5th ed. Harlow: FT Prentice Hall.

Seminar (2011). "The impact of Erasmus institutional and individual level," in the website http://www.uoc.gr/intrel/Diadosi_ekdiloseon_IKY.ppt.

Smyrnakis, A., Spanoudakis, N. Charalambous A.T., (2011). PRIME 2011: The Greek Case, Athens [in Greek].

Stephanopoulos, K., (2003). Speaking of TMP in Officers' Club of Thessaloniki, the 27/10/2003 Ling 31/10/2003

Vasiliou A., (2012). "Erasmus: 25 times are changing lives and broadens horizons," in the website http://www.kathimerini.com.cy/mobile.php?modid=2\&artid=96376 [in Greek].

Vasiliou, T., and Stamatakis, N., (2000). Dictionary of Human Sciences, Athens: Gutenberg [in Greek]. 
Weidenfeld, W., and Wessels, W., (1997). Europe from A to Z - Guidance of the European integration, European Commission, Belgium [in Greek].

Werther, W., Kaı Davis, K. (1985). Human resources and personnel management, 3rd edition, N.Y.: McGraw-Hill.

Weaver, A. (2004). "Globalisation and schooling. The case of teaching and learning ", Management Update, Vol 31 (48 - 57) [in Greek].

Xanthopoulos, T., (2002). "Public education and socio-economic development in the 21st Century: The objective data", Liberal Focus, Vol. 11 (27-31) [in Greek]

\section{Websites}

http://europa.eu/rapid/pressReleasesAction.do?reference=IP/12/83\&format=HTML\&aged=, accessed on 13/8/2012.

http://www.eu4journalists.eu/index.php/dossiers/greek/C10/, accessed on 15/8/2012.

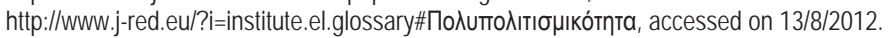

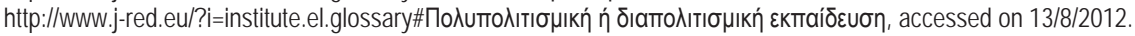

http://europa.eu/rapid/pressReleasesAction.do?reference=MEMO/12/310\&format=HTML\&aged=0\&language=EL\&guiLanguage=en, accessed on 2/8/2012.

http://www.media.uoa.gr, accessed on 2/8/2012.

http://www.panteion.gr/index.php/anakoinoseis-menu/586--erasmus-, accessed on 12/8/2012.

http://erasmusu.com/en/erasmus-blog/erasmus-scholarships/erasmus-programme-81224, accessed on 10/8/2012.

http://compus.uom.gr/erasmus/?q=el/general, accessed on 13/8/2012.

http://issuu.com/iservice-europa/docs/eac-erasmus25 brochure 120420 el ipad?mode=window\&viewMode=doublePage, accessed on 10/8/2012.

http://news.kathimerini.gr/4dcgi/_w_articles_ell_100050_07/07/2012_488231, accessed on 10/8/2012.

http://ec.europa.eu/education/lifēlong-learning-programme/doc80_en.htm, accessed on 11/8/2012.

http://compus.uom.gr/erasmus/files/file/xartis_foititi_erasmus.pdf, accessed on 7/8/2012.

http://www.tovima.gr/relatedarticles/article/?aid=103297, accessed on 3/8/2012.

http://www.european.aua.gr/socempeir.htm, accessed on 10/8/2012.

http://www.esn.org, accessed on 13/8/2012.

http://e-thessalia.gr/?p=22831, accessed on 7/8/2012.

http://ec.europa.eu/education/erasmus/doc/stat/1011/countries/greece_en.pdf, accessed on 5/8/2012.

http://eacea.ec.europa.eu/index_en.php, accessed on 10/8/2012.

http://erasmusu.com/en/erasmus-blog/erasmus-scholarships/erasmus-programme-81224, accessed on 10/8/2012.

http://www.ecolligence.net/2012/07/erasmus-experience-and-your-career.html, accessed on 12/8/2012.

http://www.imdb.com/title/tt0283900/, accessed on 10/8/2012.

http://www.teilar.gr/eu/index_gr.php, accessed on 14/8/2012

http://www.uoc.gr/intrel/MP_Introduction.ppt, accessed on 10/8/2012.

http://ec.europa.eu/cyprus/news/speeches/archives/20120208_speech_el.htm, accessed on 12/8/2012.

http://www.iht.com/articles/2005/04/26/news/enlarge2.php, accessed on 5/8/2012.

http://www.tovima.gr/world/article/?aid=440512, accessed on 14/8/2012.

http://www.teilar.gr/upfiles/PARTNERS-TEI-L-2.pdf, accessed on 14/8/2012.

http://www.in2life.gr/everyday/modernlife/articles/233505/article.aspx, accessed on 14/8/2012.

http://www.iky.gr, accessed on 14/8/2012.

http://ec.europa.eu/dgs/education_culture/valorisation/index_en.html, accessed on 17/8/2012.

http://virtualschool.web.auth.gr/3.2/Praxis/Michalis.html,accessed on 17/8/2012.

http://xenesglosses.eu/2012/05/erasmus-201011/, accessed on 19/8/2012.

http://register.consilium.europa.eu/pdf/en/09/st09/st09845.en09.pdf, accessed on 19/8/2012.

http://ec.europa.eu/llp, accessed on 19/8/2012.

http://publications.europa.eu, accessed on 19/8/2012.

http://ec.europa.eu/education/programmes/lp/structure/erasmus_en.html, accessed on 19/8/2012.

http://ec.europa.eu/education/not_found_en.htm, accessed on 19/8/2012.

http://ec.europa.eu/dgs/education_culture/index_en.html, accessed on 19/8/2012.

https://ojs.kauko.lt/index.php/stmd/article/download/176/170, accessed on 19/8/2012.

http://www.teilar.gr/, accessed on 14/8/2012.

http://europa.eu/about-eu/countries/member-countries/greece/index_en.htm, accessed on 20/8/2012.

http://europa.eu/rapid/pressReleasesAction.do?reference=IP/11/675\&format=HTML\&aged=0\&language=EL, accessed on 28/8/2012.

http://ec.europa.eu/education/erasmus/doc920_en.htm, accessed on 28/8/2012.

http://www.uoc.gr/intrel/Diadosi_ekdiloseon_IKY..$p p t$, accessed on 29/8/2012.

http://ec.europa.eu.institutions/index_e.htm, accessed on 3/9/2012.

http://we-mean-business.europa.eu, āccessed on 3/9/2012.

\section{Institutional Texts}

Lifelong Learning Programme (LLP) Guide 2012, Part I: General provisions, Brussels.

European Parliament, (2012), Erasmus for all - Executive Summary (2014-2020), Belgium [in Greek]. 
Opinion of the Committee of the Regions on the «Erasmus for All» (2012 / C 225/15) [in Greek].

European Commission (2011). Press release on the program Erasmus: Number of students for which the EU grants scholarships for studies and placements abroad amounted to an unprecedented level, Brussels [in Greek].

Council of the EU, (2011). Proposal for a Council Recommendation Youth on the move - promoting the learning mobility of young people Political agreement, Brussels, 9036/2011.

L. 4009/2011 "Structure, function, quality assurance studies and internationalization of higher education," Gazette, 195/6-9-2011.

Opinion of the Committee of the Regions Erasmus for all - Amendments by the rapporteur Renstrom Y., CdR 400/2011, rev. 1,

EU (2010), Consolidated Version of the Treaty on EU and the Treaty on the Functioning of the EU - Charter of Fundamental Rights of the EU, Luxembourg [in Greek].

Commission of the European Communities (2009), Green Paper - Promoting the learning mobility of young people, COM (2009), 329 final, Brussels [in Greek].

Communication from the Commission to the Council, the European Parliament, the European Economic and Social Committee and the Committee of the Regions of 6/12/2007 titled "Mobility, an instrument for more and better jobs: The European Action Plan for Mobility at work (2007-2010) »[COM (2007) 773 final - not published in the Official Journal] [in Greek].

Green Paper of 8/7/2009 - Promoting the learning mobility of young people [COM(2009) 329 final - Not published in the Official Journal].

Communication of 13/2/2002, to the Council, the European Parliament, the Economic and Social Committee and the Committee of the Regions Action Plan for skills and mobility [COM (2002) 72 final - not published in the Official Journal] [in Greek].

Resolution of the Council and the Representatives of the Governments of the Member States, meeting within the Council, of 14/12/2000, concerning an action plan for mobility, [Official Journal C 371 of 23/12/2000].

European Commission (2000), Report of the Commission - Research on the socio-economic background of students the program Erasmus, COM/2000/0004 final [in Greek].

Declaration of Bologna 19/6/1999 - Joint declaration of the European Ministers of Education [not published in the Official Journal] [in Greek].

European Commission (1997), Communication from the Commission for a Europe of Knowledge, COM (97) 563 final, Brussels, $12 / 11 / 1997$ [in Greek].

L. 2413/1996 "The Greek education abroad, intercultural education and other provisions", FEK 124A-1996 [in Greek].

EU, (1995), White paper on education and training. Teaching and learning - Towards the learning society, Brussels.

Annex 1: Questionnaire for Exhibition Studies of Erasmus students

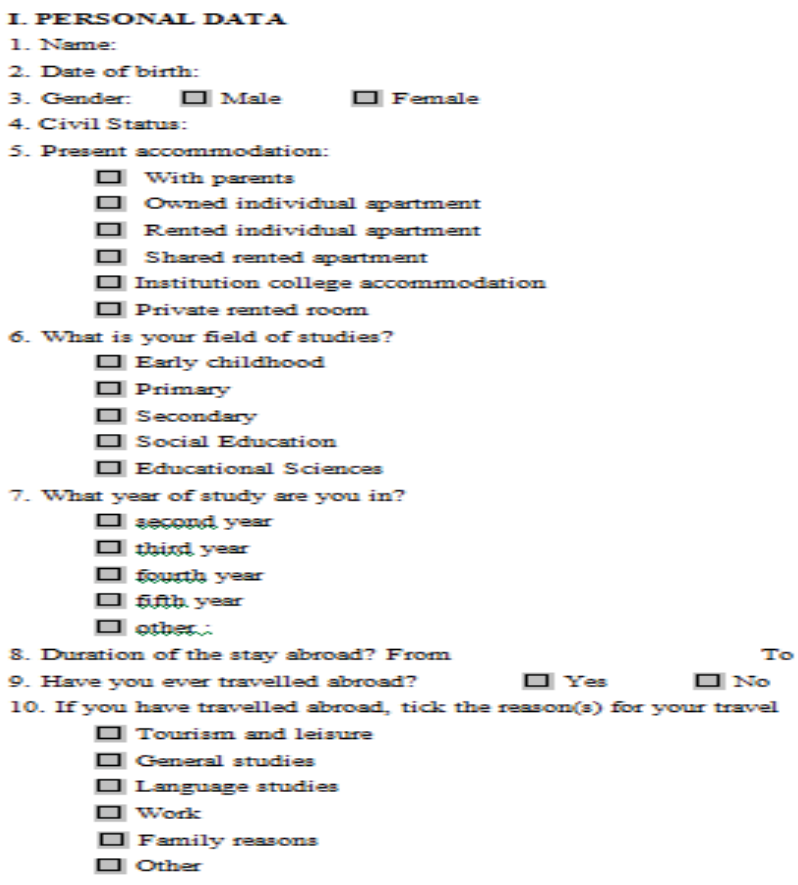


ISSN: 2239-978X

E-ISSN: 2240-0524
Journal of Educational and Social Research MCSER Publishing, Rome-Italy
Vol. 3 No. 3

September 2013

11. Have you spent more than two months in one stay abroad? $\square$ Yes $\square$ No

12. Do you feel European?

\begin{tabular}{|l|l|l|l|}
\hline 1 & 2 & 3 & 4 \\
\hline$\square$ & $\square$ & $\square$ & $\square$ \\
\hline
\end{tabular}

\section{ERASMUS PROJECT}

13. When did you decide to participate in an ERASMUS programme?

$\square$ One year before departure

$\square$ Two years before departure

$\square$ More

14. How did you obtain information about the Erasmus programme?

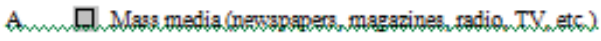

B $\square$ Friends/acquaintances before I started my studies

C $\square$ Friends/study mates during the study

D $\square$ Information at start up of courses

E $\square$ Information from the intemational coordinator visiting my group/course

F $\quad$ Appointment at the intemational coordinators office

G $\square$ Information days for students

H $\quad$ Your institution intemational web page

I $\square$ Qther institution intemational web page

J $\square$ If other please indicate which

15. Which of the above mentioned points did mostly influence your decision?

口ADB पCDD

16. To which extent did each of the following motives influence your decision to take part in the ERASMUS programme? Please give a score from 1 to 4 (1 for the least important, 4 for the most).

\begin{tabular}{|l|c|c|c|c|}
\hline & 1 & 2 & 3 & 4 \\
\hline To improve your CV & $\square$ & $\square$ & $\square$ & $\square$ \\
\hline Leam about different didactic methods & $\square$ & $\square$ & $\square$ & $\square$ \\
\hline To improve knowledge of languages & $\square$ & $\square$ & $\square$ & $\square$ \\
\hline To visit a foreign country & $\square$ & $\square$ & $\square$ & $\square$ \\
\hline To accompany friends & $\square$ & $\square$ & $\square$ & $\square$ \\
\hline To live independently & $\square$ & $\square$ & $\square$ & $\square$ \\
\hline
\end{tabular}

\begin{tabular}{|l|c|c|c|c|}
\hline Enhance your job opportunities after graduation & $\square$ & $\square$ & $\square$ & $\square$ \\
\hline Leam about another culture & $\square$ & $\square$ & $\square$ & $\square$ \\
\hline To make friends in another part of the world & $\square$ & $\square$ & $\square$ & $\square$ \\
\hline To feel European & $\square$ & $\square$ & $\square$ & $\square$ \\
\hline To experience life as a foreigner & $\square$ & $\square$ & $\square$ & $\square$ \\
\hline To experience a feeling of adventure & $\square$ & $\square$ & $\square$ & $\square$ \\
\hline For personal development & $\square$ & $\square$ & $\square$ & $\square$ \\
\hline To benefit from the Erasmus grant & $\square$ & $\square$ & $\square$ & $\square$ \\
\hline Problems with the study programme at home institution & $\square$ & $\square$ & $\square$ & $\square$ \\
\hline Higher quality of the study programme at the host institution & $\square$ & $\square$ & $\square$ & $\square$ \\
\hline Study programme not available at the home institution & $\square$ & $\square$ & $\square$ & $\square$ \\
\hline As a part of my career planning & $\square$ & $\square$ & $\square$ & $\square$ \\
\hline To experience life in a new environment & $\square$ & $\square$ & $\square$ & $\square$ \\
\hline
\end{tabular}

Qther reason, Please spacify 
ISSN: 2239-978X

E-ISSN: 2240-0524
Journal of Educational and Social Research MCSER Publishing, Rome-Italy
Vol. 3 No. 3

September 2013

17. What is the name of your host Institution?

18. Why did you choose the host institution?

\begin{tabular}{|l|l|l|l|l|}
\hline & 1 & 2 & 3 & 4 \\
\hline Becsuse you are interested in that particular country & $\square$ & $\square$ & $\square$ & $\square$ \\
\hline Becsuse you are interested in that particular institution & $\square$ & $\square$ & $\square$ & $\square$ \\
\hline Beccuse you are interested in that particular town place & $\square$ & $\square$ & $\square$ & $\square$ \\
\hline Beccuse you want to leam a new language & $\square$ & $\square$ & $\square$ & $\square$ \\
\hline Beccuse you want to improve my lnowledge of the language & $\square$ & $\square$ & $\square$ & $\square$ \\
\hline Beccuse you already lnow the language & $\square$ & $\square$ & $\square$ & $\square$ \\
\hline Beccuse it was recommended by former Erasmus students & $\square$ & $\square$ & $\square$ & $\square$ \\
\hline Because it was recommended by the home intemational coordinator & $\square$ & $\square$ & $\square$ & $\square$ \\
\hline Because you had no other option & $\square$ & $\square$ & $\square$ & $\square$ \\
\hline
\end{tabular}

Other resson. Plesse specify

19. To what extent do you fear any of the following before beginning the ERASMUS programme?

\begin{tabular}{|l|c|c|c|c|}
\hline \multicolumn{1}{|c|}{} & 1 & 2 & 3 & 4 \\
\hline Not to have enough money & $\square$ & $\square$ & $\square$ & $\square$ \\
\hline Not to find suitable lodgings & $\square$ & $\square$ & $\square$ & $\square$ \\
\hline
\end{tabular}

\begin{tabular}{|l|c|c|c|c|}
\hline To fael alone/lonely & $\square$ & $\square$ & $\square$ & $\square$ \\
\hline Not to be able to adapt to the customs of the country & $\square$ & $\square$ & $\square$ & $\square$ \\
\hline To have problems with the language of instruction & $\square$ & $\square$ & $\square$ & $\square$ \\
\hline To have problems with the language of the host country & $\square$ & $\square$ & $\square$ & $\square$ \\
\hline Not to be able to adapt to the Education Faculty & $\square$ & $\square$ & $\square$ & $\square$ \\
\hline Not to achieve recognition of the credits in your own Institution & $\square$ & $\square$ & $\square$ & $\square$ \\
\hline To have difficulties on your retum in continuing with your studies & $\square$ & $\square$ & $\square$ & $\square$ \\
\hline To obtain a lower average result on your academic record & $\square$ & $\square$ & $\square$ & $\square$ \\
\hline Not to be able to communicate with the pupils during teaching practica & $\square$ & $\square$ & $\square$ & $\square$ \\
\hline Not to be able to communicate with the pupils in practice & $\square$ & $\square$ & $\square$ & $\square$ \\
\hline
\end{tabular}

20. How are you preparing for your stay abrosd?

\begin{tabular}{|l|c|c|c|c|}
\hline & 1 & 2 & 3 & 4 \\
\hline $\begin{array}{l}\text { By improving your lnowledge of the language of instruction usad for } \\
\text { exchange students }\end{array}$ & $\square$ & $\square$ & $\square$ & $\square$ \\
\hline By improving your lnowledge of the langusges spolen in the country. & $\square$ & $\square$ & $\square$ & $\square$ \\
\hline By obtaining information about the host country & $\square$ & $\square$ & $\square$ & $\square$ \\
\hline By obtaining information about the host faculty & $\square$ & $\square$ & $\square$ & $\square$ \\
\hline By preparing a work plan with your local intemational coordinator & $\square$ & $\square$ & $\square$ & $\square$ \\
\hline By contacting former Erasmus students/scholars at your home Institution & $\square$ & $\square$ & $\square$ & $\square$ \\
\hline By contacting ERASMUS students from other countries & $\square$ & $\square$ & $\square$ & $\square$ \\
\hline By contacting the ERASMUS Student Network & $\square$ & $\square$ & $\square$ & $\square$ \\
\hline By contacting teachers at the host faculty & $\square$ & $\square$ & $\square$ & $\square$ \\
\hline $\begin{array}{l}\text { By obtaining information about the academic activities you will be } \\
\text { doing in the host faculty }\end{array}$ & $\square$ & $\square$ & $\square$ & $\square$ \\
\hline By doing nothing in particular & & & & \\
\hline
\end{tabular}

21. Do you have any command of the language spolken in the country you are going to?

$$
\text { No } \square \quad \text { little } \square \quad \text { Well } \square \quad \text { Very well } \square
$$

22. How much support did you receive from your personal and academic environment?

\begin{tabular}{|l|c|c|c|c|}
\hline & 1 & 2 & 3 & 4 \\
\hline Family & $\square$ & $\square$ & $\square$ & $\square$ \\
\hline Class mates & $\square$ & $\square$ & $\square$ & $\square$ \\
\hline Friends & $\square$ & $\square$ & $\square$ & $\square$ \\
\hline
\end{tabular}




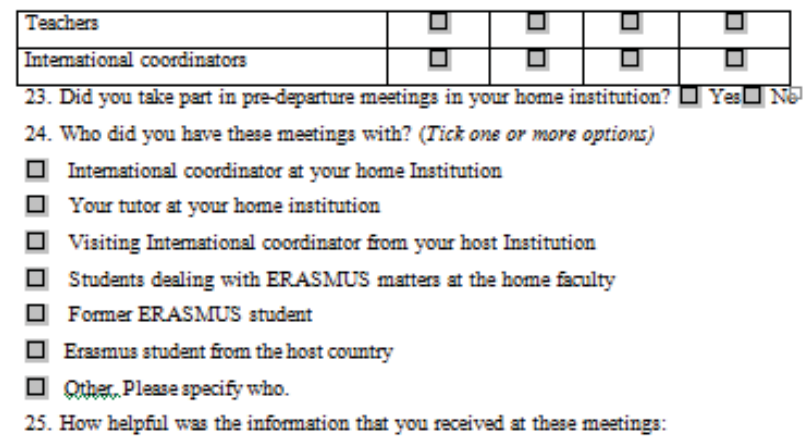

\begin{tabular}{|l|c|c|c|c|}
\hline & 1 & 2 & 3 & 4 \\
\hline Academic issues & $\square$ & $\square$ & $\square$ & $\square$ \\
\hline Economic issues & $\square$ & $\square$ & $\square$ & $\square$ \\
\hline Cultural issues & $\square$ & $\square$ & $\square$ & $\square$ \\
\hline Daily life (jowrney, lodgings, transport, times, etc.) & $\square$ & $\square$ & $\square$ & $\square$ \\
\hline
\end{tabular}

Qther Please specify

26. From whom did you receive support to choose your courses abrosd?

\begin{tabular}{|l|c|c|}
\hline & Yes & No \\
\hline Home institution & $\square$ & $\square$ \\
\hline Host institution & $\square$ & $\square$ \\
\hline Intemet & $\square$ & $\square$ \\
\hline Former Erasmus students & $\square$ & $\square$ \\
\hline
\end{tabular}

Qther. Please spacify:

27. Before your departure, do you know which courses you are going to attend in your host Institution? $\square$ Yes $\square$ No

28. Are you going to sign a Leaming Agreement before departure? $\square$ Yes $\square$ No 29. Before starting your ERASMUS programme do you lnow if the credits included in the Laaming Agrement are going to be recognized in your home institution?

$\square$ Yes $\square$ No

III. PRACTICAL ASPECTS

30. Do you have another grant besides the ERASMUS grant? $\square$ Yes $\square$ No

31. In your opinion, will your grant be adequate? $\quad \square$ Yes $\quad \square$ No

32. If not, please say what action you are taking?

$\square$ Work before leaving

$\square$ Try to spend less

$\square$ Ask your parents for monay

$\square$ Ask the bank for a loan

$\square$ Use your savings

$\square$ Look for work in the host country

Qther. Please specify:

33. Who will find your accommodation in the host country?

ㅁ Home Institution

․ Host Institution

ㅁ Personal initiative

34. Do you know the conditions for benefiting from health assistance in the host country?
ㅁ Yes
$\square \quad$ No

35. Had you made or are you going to make provisions so as to be insured for the duration of your stay abroad?
$\square \quad$ Yes
$\square \quad$ No 